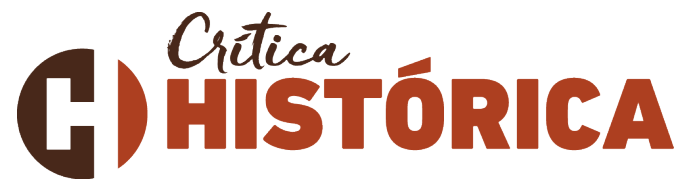

\section{Cinco documentos para a História da Comarca das Alagoas. Contribuição para os estudos demográficos, econômicos, geográficos e administrativos, I749-1814}

Cinco documentos para la História de la Comarca de las Alagoas. Una contribución para los estudios demográficos, económicos, geográficos e administrativos, c. I749-I8I4

Alex Rolim Machado*

Resumo: O presente artigo espera trazer a lume, de maneira científica, crítica e problemática, a existência de novos códices e conjuntos documentais essenciais para a pesquisa e a escrita da História das Alagoas do período Colonial.

Palavras-chave: Alagoas Colonial, Arquivos, Documentos Coloniais.

Resumen: El presente artigo espera presentarse, de manera científica y problemática, la existência de nuevos códices y conjuntos documentales esenciales para la investigación e y la escritura de la Historia de las Alagoas del período Colonial.

Palabras clave: Alagoas Colonial, Archivos, Documentos Coloniales.

"Se listarmos os produtos levados para trocar ao Congresso Cooperativo em Liverpool, em outubro de I832, também poderemos ver as pessoas" (THOMPSON, I98I, p. 393).

* Mestre em História pela Universidade Federal de Alagoas; doutorando em História pela Universidade Federal de Pernambuco. Membro do Grupo de Estudos América Colonial (GEAC-UFAL). Agradeço as leituras de Everton Rosendo (mestrando UFRPE) na versão preliminar desse texto. Esse artigo contou com financiamento de bolsa de Doutorado CAPES. 


\section{Introdução}

Desde o início de uma faculdade, voltada para a graduação em História, aprendemos com outros historiadores (sejam os professores, convidados, palestrantes, colegas de trabalho ou os que só conhecemos pelos livros) que um documento não é um fim nele mesmo; que não dará todas as respostas prontas para o pesquisador; e que sua criação e salvaguarda em algum arquivo é fruto de posições pessoais e institucionais que devem ser entendidas em seus momentos históricos. Ou seja, uma evidência não exclusivamente ajuda a contar uma história, ela é formada de histórias (BLOCH, 2OII; FEBVRE, I989; CERTEAU, 20I0; FOUCAULT, 2012; LE GOFF, 2003).

Fruto de conversas acerca da necessidade de retomada do Projeto do Banco de Dados do GEAC (Grupo de Estudos América Colonial, coordenado pelo Prof. Dr. Antonio Filipe Pereira Caetano), aliado com a obrigação de socializar a documentação para futuros pesquisadores (de qualquer área), uma série de artigos e ensaios foi pensada a partir das pesquisas desenvolvidas dentro do grupo: escritos sobre - e com - Documentos Vários que sirvam como pontos referenciais para leitores e pesquisadores.

Nesse artigo, os primeiros Documentos Vários que irão iniciar serão aqueles que, tradicionalmente, são usados na historiografia brasileira ou sobre o Brasil ${ }^{\mathrm{I}}$. As relações, mapas estatísticos, corográficos, relatos de cronistas, mapas cartográficos, lista de governadores ou altos comandantes, etc... Seus usos foram e continuam sendo variados, cabendo a cada historiador problematizá-los na medida do possível, no decorrer de suas próprias indagações. Essa escolha liga-se ao momento histórico da Universidade Federal de Alagoas (campus Maceió e Delmiro Gouvêa) e da Universidade Estadual de Alagoas, em especial os seus quadros de pesquisadores internos de graduação, mestrado e doutorandos que tiveram que ir para outras universidades: os atuais estudos voltados para a demografia histórica, prosopografia e pesquisas acerca de escravidão (CAETANO (org.), 20I0, 2012, 2015, 20I7; MACIEL (org.) 20II; CARVALHO \& SILVA (orgs.), 20I7). Temáticas que lidam diretamente com esses Documentos agora transcritos, principalmente, os que concernem à época colonial.

Pode-se dizer que estamos bem imbuídos de uma dupla prática na escrita da História: a do uso de documentos de caráter administrativo e de gestão, e a construção de novos a partir de diversas fontes e indícios. Lê-se e cria-se a todo o momento censos, listas, relações,

\footnotetext{
${ }^{\text {I }}$ Parto de Francisco Adolpho Varnhagen (VARNHAGEN, I956), que, inclusive, encontrou e editou relações, documentos primários, listas e cronistas da época do Brasil Colonial, passando por José Honório Rodrigues (RODRIGUES, 1979), chegando até o mais humilde trabalho acadêmico do mais simples simpósio temático de qualquer colóquio/congresso/encontro que seja em qualquer local do Brasil.
} 
tabelas, quadros, livros de contabilidade e fiscais, registros paroquiais, descrições de rios, de povoados, contabilizações de fogos, habitantes, enumeração de instituições diversas, etc... Essa atitude, geralmente, tem um duplo intuito: o de dar uma base para que o escritor estabelecesse o mundo em que se desenrolavam os acontecimentos que pretendia relatar, ou as críticas e posições que queira passar com as suas letras; e o de apontar uma visão geral de uma sociedade como um todo (ou como um corpo), em que, matematicamente, tudo deveria ser contabilizado para que certa ordem fosse apreendida, pensada, e posta em prática para diversos fins ${ }^{2}$.

Tais informações eram as mais propícias para se entender uma sociedade, em termos mais objetivos. Eram bases para se construir um mundo onde os personagens e os acontecimentos se movimentavam sobre. E, arrisco-me a dizer que eles eram, e continuam sendo hoje em dia, os documentos principais para desenvolver a prática do contexto histórico, seja para o famoso/famigerado "Introdução/capítulo I" de qualquer trabalho acadêmico, seja graduação, mestrado ou doutorado, seja para prender a atenção de um leitor leigo, inserindo-o no ambiente colonial.

Essa linha de raciocínio perdurou e teve seu ápice nos anos 1940-80 na França, Portugal, Espanha e Brasil nos estudos sobre a época moderna (nosso interesse aqui). Análises de econometria, demografia histórica, serial, curvas de preços e mercadorias, cotação de moedas; utilizados para a história econômica e social, visando observar os movimentos sociais de acordo com os contextos denominados como "conjunturas", para se criar explicações e hipóteses para determinados acontecimentos (como se formaram; qual foi o "gatilho" principal; motivações diversas, etc.) (BRAUDEL, I972; MAURO, I969; GODINHO, I968, I973; VILAR, I982; CARDOSO \& BRIGNOLI, 2002; CIPOLLA, I993).

Mesmo com o advento (que existiu paralelamente à história socioeconômica e serial) da "história das mentalidades", que degringolou para o termo mais abrangente "cultural", a história social que se baseava, em boa medida, em documentos administrativos e "gerais" continuava em voga (CARDOSO, VAINFAS (orgs.), 20I2; DOSSE, I992; BARROS, 2OI4; HOBSBAWM, 1998). Nunca deixou seu poder dentro do campo da historiografia e, com o decorrer do tempo, sofreu mutações, críticas internas e externas para se adaptar aos novos anseios da escrita e pesquisa histórica, a partir das problemáticas que eram levantadas internamente (dentro da história social e em relação com outras vertentes), e que eram

\footnotetext{
${ }^{2}$ Apesar de ser um texto curto (e antigo), interessante as falas de GOUBERT, 1973.
} 
também trazidas de questionamentos advindos do exterior (a vida cotidiana, situações políticas, culturais, sociais, religiosas e econômicas diversas e contemporâneas) $)^{3}$.

"Básico"; "objetivo"; "história socioeconômica da década de I940-80"; "estatística"; "criticado"; "conjuntura"; "fato histórico"; "capítulo de contextualização". Um aluno universitário nos dias atuais é praticamente disciplinado, desde o início de um curso de História, a ter ojeriza a essas palavras, transformando-as muitas vezes em conceitos vazios, usados como inimigos para defender sua posição no campo da historiografia. Quem quer se tornar um historiador que pratica esse tipo de história, tão criticada nos corredores e em salas de aula, e ainda em congressos, simpósios, colóquios, entrevistas, livros diversos?

Mas, o pior não é criticar uma história demográfica, serial, econômica, estatística, de relações, números, listas, etc. O efeito mais nocivo das lutas internas entre historiadores é quando as evidências são reduzidas exclusivamente a uma função, a um campo neutro onde sua utilização não é dada nos moldes de métodos históricos, mas na sua obrigação em utilizá-lo para conseguir um determinado fim, que agrade a todos. No caso dos documentos que aqui serão expostos: oferecer informações para estabelecer limites de um universo possível, retirando deles suas cargas ideológicas e impedindo leituras críticas a partir de teorias.

Outro problema nos documentos é quando eles se tornam explicativos de uma totalidade a partir de sua criação. Um texto de 1780 , por exemplo, com suas informações estatísticas variadas, é utilizado em um sentido positivista de progresso, como se as informações retiradas de $\mathbf{I} 780$ fossem "maiores" ou "melhores" do que poderia ter sido em I680, o que faz com que a imaginação - e não a procura por novas evidências - explicasse a lacuna dos Ioo anos. Ou para ser mais exato, a relação de Engenhos de Açúcar, concernente às vilas que faziam parte da Comarca das Alagoas, retirada da Ideia da População da Capitania de Pernambuco de I774-1789, é maior do que a retirada da Informação Geral da Capitania de Pernambuco de I749. Isso pode induzir o historiador a não problematizar o aumento de Engenhos de Açúcar e, consequentemente, adotar explicações fáceis de que isso era "natural" ou que o território das "Alagoas" estava predestinado (por conta do clima e do solo) ao cultivo da cana de açúcar. Décadas de vivência histórica são suprimidas por explicações imaginativas (que algumas vezes não deixam de serem corretas e certeiras) e, o mais perigoso, pela sedução das informações dadas na documentação, anestesiando o pesquisador com o que encontra, deixando-o ludibriado pela "exatidão" do que está escrito. Se números dizem que houve aumentos de

\footnotetext{
${ }^{3}$ Para o âmbito da História Colonial (com aquela puxada para o Rio de Janeiro), em especial FRAGOSO. GUEDES. SAMPAIO (orgs.), 20I4. Para a Europa (com aquela puxada pra França), cf. LE GOFF. CHARTIER. REVEL. (dir.), I990. Para um panorama geral, cf. BURKE, 2012.
} 
Engenhos, por que se deveria dar ouvidos a Senhores da Cana que reclamam de falências e de diminuição dos mesmos Engenhos na Comarca das Alagoas? A resposta é desmentir ou problematizar?

Historiadores que utilizam da primeira posição estão em extinção. Afinal, os números não são respostas para indagações sociais provenientes das problematizações feitas a documentos diversos. Todavia, para retornar ao raciocínio, não é raridade encontrar pesquisadores que não problematizam os dados inseridos nas Relações, Mapas Estatísticos e "Corográficos", e que as tratam como documentos de contextualização, cuja finalidade é dar informações gerais para que o escritor possa desenvolver seu raciocínio, dentro de um mundo material mais seguro. Afinal, ele foi matematicamente desenvolvido (e, às vezes, o pesquisador nem se sente na obrigação de problematizar as manipulações); no caso de natureza geográfica, ele é tido, muitas vezes, como imutável e imóvel ${ }^{4}$.

Agora vem uma parte incongruente do presente texto: essa última posição não é de todo errada. Ela não representa "antiprofissionalismo" ou alguma ação imoral ou antiética com a pesquisa histórica. Nem todo pesquisador é obrigado a se valer desse tipo de Documentos e problematizá-los em mínimos detalhes, em um espiral infinito. Até porque, se o pesquisador está interessado em demonstrar uma tese/hipótese, ele trilhará caminhos diferentes e interrogará as evidências de maneira distinta de outros. Assim, acontece de historiadores pegarem informações "frias" de Mapas Estatísticos e transpô-los para seu trabalho, como um conhecimento extra para criticar, comprovar, refutar ou problematizar outras posições que tenham pouco ou nada a ver com a história e composição do documento em que se encontra o Mapa Estatístico (as discussões - e até mesmo brigas entre quem faz isso e os que dispendiam seu tempo em analisar e estudar em profundidade o Documento é outra história). Apesar de parecer simplista, quase o mesmo pode ser aplicado às imagens, que não podem ser utilizadas exclusivamente para ilustrar argumentos (dando um caráter mais didático), mas que contêm uma história e, podem ser estudadas e problematizadas a partir de métodos próprios e interdisciplinares. No entanto, mesmo assim, seu uso para ilustrações (beleza, didática, relaxar a vista) não pode ser considerada um erro ou uma ação desrespeitosa com quem estuda a História da Arte, apesar de que o ato de "copiar-e-colar" imagens de maneira mais ou menos aleatória e sem tratamento crítico prévio, também não possa ser considerado uma ação permitida (VIEIRA. 20I4; MENESES, 20I2, p. $\left.252^{5}\right)$.

\footnotetext{
${ }^{4}$ Interessante a leitura de ALMEIDA, 20II.

5 "O efeito mais nocivo, porém, entre nós, encontra-se imediatamente a tema e ilustração, de modo que as conclusões de análises dependem exclusivamente do que as fontes textuais já haviam postulado”.
} 
Para que serve, então, esse texto? Depois desse arrodeio, era mais fácil fazer uma apresentação de cada documento, transcrevê-los, desejar sorte para os futuros leitores e deixar as ações acontecerem. Porém, voltaríamos ao início dessas linhas, em que os documentos poderiam ser encarados como meros informantes de dados e contextualizadores (assim, essa crítica poderia cair no autor desse artigo, que poderia ser taxado de irresponsável por sair distribuindo a torto e a direito documentação, que deve ser problematizada, pois todo artigo é, também, uma posição social).

O que será proposto adiante é a tentativa de entender a Nomenclatura dos Documentos transcritos, inserindo-os na História de seu tempo a partir do vocabulário, tentando encontrar, para isso, sua caracterização a partir do nome dado a ele. Julga-se esse ponto como primordial para depois adentrar-se na História do documento: as motivações que o levaram a ser pensado, escrito, divulgado e salvaguardado.

\section{Nomenclatura e História}

Para reforçar o entendimento da História do Documento, um ponto importante a se ressaltar é a nomenclatura dada à Documentação aqui transcrita. Ela pode ser de três tipos: Relação; Mapa Estatístico; Mapa Corográfico. Os dois primeiros constam nos Originais, tendo sido escritos pelos homens de sua época, para estabelecer o tipo de informação que continha nos papéis. A última documentação é arbitrária e artificial, feita pelo ex-dono, ou responsáveis pelo Arquivo que salvaguarda o texto. Para estabelecer o que significa cada palavra, recorre-se ao Padre D. Raphael Bluteau, autor do Dicionário mais utilizado para estudos de palavras e seus significados em Portugal na época de Antigo Regime; mas também conjugando leituras nos dicionários de Antonio de Moraes Silva (1789) e Luiz Maria da Silva Pinto (I830).

Relação, nos idos de I749, poderia ser entendida com vários significados. O que se assemelha mais ao caso dos Documentos é o de "Narração de alguma coisa que sucedeu". Ou seja, na nossa ocorrência, a Narrativa contabilística de um determinado conjunto de coisas elou pessoas (ofícios, engenhos, instituições, igrejas, escravos, mulheres, homens, crianças, pardos, forros, etc), visto não haver uma História para justificar essa Relação. Para reforçar o argumento da Contabilidade como início de uma troca de informações, D. Bluteau também indica que Relação pode ser: "Comunicação, ou correspondência, que uma pessoa tem com outra" (BLUTEAU, I712-I728, vol. 7, pp. 214-215). Cruzando os séculos (mas sem perder o fio da meada), Aurélio Buarque de Holanda Ferreira estabeleceu um 
significado maior para Relação: "Ato de relatar; relato. Descrição, notícia, informação" (FERREIRA, I988, p. 560).

Pode-se dizer que todo Mapa Estatístico é uma Relação, mas nem toda Relação é um Mapa Estatístico, e a diferença residi na maneira como ele é desenvolvido e apresentado. Um Mapa (de navios, de produtos, estatístico, populacional, de engenhos, de Igrejas, etc) é mais bem elaborado no sentido gráfico. Normalmente é desenhado, como uma Tabela nos dias atuais, com delimitações, com divisões e, às vezes (como nas Relações), somas totais. Os Mapas podem ser feitos tanto em formato circular, como retangular, com suas divisões e subdivisões dentro deles. Para Bluteau, Mapa é: "Carta Geográfica, \& hidrográfica, em que se representam em dois planisférios o antigo, \& novo mundo" (BLUTEAU, I712-I728, vol. 5, p. 313). Nesse caso, infelizmente, o grande dicionarista não é de nenhuma ajuda (nem a palavra "Estatística" existe no Dicionário). Somente em I789, com Antonio de Moraes e Silva, é que se tem um exemplo de um Mapa que não seja Geográfico nem Astronômico: "Lista: v.g. mapa dos soldados de uma Companhia, ou Regimentos" (SILVA, I8I3, vol. 2, p. 266).

Mapa Corográfico, por sua vez, sendo uma expressão utilizada no século XIX ou XX (pois não se sabe a época em que ele foi catalogado), pode ter duas definições. Pelo Dicionário de Luiz Maria da Silva Pinto de I830, tem-se Corográfico como "Descrição de uma terra em particular" (PINTO, I832). Pelo Dicionário de Aurélio Buarque de Holanda, a Corografia é o "estudo ou descrição geográfica de um país, região, província ou município" (FERREIRA, I998, p. I80). Essas informações são importantes para ressaltar o caráter artificial do nome e da composição do Documento, assunto para mais adiante.

Unindo essas definições tem-se uma ideia melhor apurada (que não é infalível) da Documentação que se tem aqui.

\section{A documentação e suas Histórias}

Sem mais delongas, chega-se ao que de fato interessa a muitos: a apresentação prévia dos documentos aqui transcritos, manipulados ou não. Mas, antes, algumas outras palavras devem ser proferidas.

Dois dos documentos já foram anteriormente publicados, inclusive em Alagoas, e são velhos conhecidos pelos pesquisadores, desde Manuel Diégues Júnior, passando por Moacir Sant'Anna, Dirceu Lindoso e Luíz Sávio de Almeida; e; ainda por nós do GEAC (DIÉGUES Jr., 2006; SANT'ANNA, I970; LINDOSO, 2005, 2015; ALMEIDA, 2008; CAETANO (org.), 20I0, 20I2, 20I5): a Informação Geral da Capitania de Pernambuco e a 
Ideia da População da Capitania de Pernambuco, ambos nos Anais da Biblioteca Nacional do Rio de Janeiro e, posteriormente, na Revista do Instituto Histórico e Geográfico de Alagoas (Revista do Instituto Arqueológico e Geográfico Alagoano, 1927, pp. I86-20I, 209-228) ${ }^{6}$. Todavia, por conta da riqueza de detalhes e do espaçamento de tempo entre um e outro documento (I749 e I774), algumas situações aconteceram.

A primeira pode soar como crítica ferrenha, mas não deve ser lida dessa maneira. Por conta da facilidade de acesso, ambos os conjuntos documentais se tornaram viciantes nos trabalhos. Graças a eles, se poderiam abarcar um longo período de tempo, podendo fazer previsões imaginativas para trás de 49 e para frente de 74 e, com isso, ter um bom parâmetro do século XVIII “alagoano”. E, é aí que reside o problema. Diégues Júnior, Sant'Anna, Lindoso e Almeida fizeram trabalhos indispensáveis para a História de Alagoas com tais documentações, mas pouco ou nada fizeram para procurarem outros conjuntos que suprissem as lacunas que ficavam entre os tempos (no início de nossos trabalhos do GEAC, também não fomos atrás de tantas documentações extras, excetuando Arthur Curvelo para o século XVII). Suas pesquisas se dirigiam para o século XIX; seus desbravamentos no Arquivo Público de Alagoas e no Instituto Histórico e Geográfico de Alagoas são um mapa decodificado para futuros pesquisadores; suas conclusões são fortes, firmes e ainda ressoam nos trabalhos acadêmicos atuais, mesmo aqueles buscam criticar suas teses. Mas, sobre o século XVIII (interesse mais caro à Diégues Júnior, para Dirceu Lindoso e nós do GEAC), muito falta nesses dois arquivos alagoanos. E, assim, chegamos à segunda situação.

Não existe "Alagoas" em outros arquivos fora do estado. Com exceção da Biblioteca Nacional do Rio de Janeiro e no Arquivo Histórico Ultramarino (Lisboa), o pesquisador que se enveredar no Arquivo Nacional do Rio de Janeiro, no Instituto Histórico e Geográfico Brasileiro, no Arquivo Público da Bahia, no Arquivo Nacional da Torre do Tombo, na Biblioteca da Universidade de Coimbra e na Biblioteca Nacional de Portugal, vai se decepcionar, ou pelo menos ter mais trabalho nas leituras dos Instrumentos de Pesquisa ${ }^{7}$. Cada Arquivo é construído pelas mãos de seus funcionários, com seus Instrumentos de Pesquisa peculiares (uns são fichas, outros por assunto, outros por nome, outros por localidade, os fundos são por assuntos, por pessoas, por instituições) e, o prazer e desespero do pesquisador, residem exatamente nesse ponto: se reinventar, a cada Arquivo que se vá,

\footnotetext{
${ }^{6}$ A referência aos Anais da Biblioteca Nacional será exposta adiante.

${ }^{7}$ Estou aqui citando os que visitei e pesquisei. Alguns leitores, por exemplo, irão sentir a falta de referências ao Arquivo Público Municipal Jordão Emerenciano (Pernambuco) e ao Arquivo do Instituto Arqueológico, Histórico e Geográfico Pernambucano, instituições não visitadas e pesquisadas pelo autor, mas por outros membros do GEAC como Antônio Filipe Pereira Caetano, Arthur Curvelo, Dimas Bezerra Marques e Everton Rosendo.
} 
para procurar por uma Capitania inexistente do século XVIII (isso porque, não se está escrevendo sobre o período pré-comarca das Alagoas - I500-I7I2 -, o que faz a situação ser outra).

Mas, não vamos nos alongar sobre como se deve pesquisar em Arquivos. Esse é assunto que, possivelmente, pode ser escrito em outros textos. $\mathrm{O}$ argumento que se está tentando traçar é que, por conta da dificuldade de pesquisa (dinheiro, transporte, alimentação, tempo, auxílio, moradia e etc), muitos deles estão pouco ou nada desbravados, deixando em suas gavetas fundos e códices de assuntos que não tem nada $a$ ver com Alagoas, mas que em seus interiores resguardam documentos que são de imensa valia para os Séculos XVII, XVIII e XIX. Alguns deles foram transcritos e serão dispostos agora.

O Documento or é a Informação Geral da Capitania de Pernambuco. Pelo que se diz na introdução dos Anais da Biblioteca do Rio de Janeiro, em que eles foram publicados, é uma coleção de vários documentos, que compreendem tanto o centro da Capitania como suas jurisdições (Ceará, Rio Grande do Norte, Paraíba e a Comarca das Alagoas). São documentos misturados (no tempo e no espaço), apesar de que quando há um "tema", aparecem outros escritos "relacionados", mas logo a ordem se perde novamente. Nada é dito sobre o idealizador do projeto, suas motivações e em que época foi escrita com exatidão. A data é tradicionalmente considerada como de 1749 , pois os documentos não passam de "dezembro de I748" (Anais da Biblioteca Nacional do Rio de Janeiro, 1906, pp. II7-496). De acordo com os Anais da Biblioteca:

Sob o no 5.495 figurou na Exposição de História do Brasil, conforme consta do respectivo catálogo, tendo sido posteriormente adquirido pela Biblioteca Nacional. Nele estão incluídos documentos idênticos aos que se acham no mesmo catálogo sob os nº 5.496 e 5.973 (idem, ibidem).

O termo "adquirido pela Biblioteca Nacional" dá a impressão de que o Códice é o Original, que normalmente fica resguardado quando alguma cópia é publicada, microfilmada ou digitalizada. O Original está no além-mar. Em pesquisas feitas no Arquivo Nacional da Torre do Tombo, em Lisboa, o manuscrito da Informação Geral da Capitania de Pernambuco, se encontra no Fundo Manuscritos do Brasil, sob o nome Livro 43-Papéis relativos ao Governo e História de Pernambuco. Vários desses documentos (e outros das Capitanias de São Paulo, Minas Gerais, Rio de Janeiro, Angola, Coimbra, etc) foram 
copiados para o Códice 452-Papéis Vários da Biblioteca Geral da Universidade de Coimbra ${ }^{8}$. Não é cansativo lembrar que o Livro 43 é um códice feito com cópias dos documentos, e não um calhamaço cheio de originais agrupados. Inclusive, os Mapas das cidades e das fortalezas não constam na Cópia dos Anais da Biblioteca Nacional, sendo assinalados, na página 496 como "Faltam as Plantas". Essas Plantas baixas e mapas estão no Livro 43, são coloridas e feitas à mão. Há ainda um ex-libris com as indicações "Ex-Bibliotheca Congr. Oratorii Sp. Sancti. E.N.C"9.

Francisco A. Pereira da Costa, historiador pernambucano, escritor do monumental Anais Pernambucanos, tem uma interpretação da História do Códice. Para Costa, o responsável pela compilação de documentos para o estudo da administração pernambucana foi o Governador de Pernambuco, D. Marcos de Noronha e Brito, que se tornou depois o VI Conde dos Arcos. Chegou a Pernambuco em I746 e governou até I749 e, desde o início, era versado em "fazer muitos escritos curiosos, de tudo quanto pôde fazer haver notícia em Pernambuco, desde o seu descobrimento até a época do seu governo”. Continua Costa:

Dos trabalhos mandados organizar por D. Marcos de Noronha, sob a sua imediata direção, nos resta uma excelente obra, inédita ainda, sob o título: Descrição de Pernambuco com parte da sua história e legislação até o governo de D. Marcos de Noronha em 1746 (COSTA, I984, pp. 6I-64).

Esse documento chegou às mãos de Francisco da Costa por meio de uma iniciativa do Governo da Província de Pernambuco, em I845, que mandou copiar documentos relacionados à História da Capitania nos arquivos portugueses, entre eles a Torre do Tombo. A Cópia chegou em I846, e ficou resguardada na "Secretaria do Governo [de Pernambuco]", sendo depois transferida para o Arquivo Público Estadual de Pernambuco (MELLO, I983, pp. [3-4] e [IO-II]).

Ao que parece, a História do Documento foi desvendada. Pelo "Título", já se sabe que o mesmo documento teve vários nomes. O que faz Pereira da Costa indicar como sendo a iniciativa de D. Marcos de Noronha é sua trajetória - podemos dizer - intelectualadministrativa, visto que o mesmo Governador foi quem incentivou Borges da Fonseca a escrever a Nobiliarquia Pernambucana (COSTA, 1984, pp. 62-63). Mas, permanece a

\footnotetext{
${ }^{8}$ Biblioteca Central da Universidade de Coimbra. Sessão de Reservados. Códice 452 - Papéis Vários.

${ }^{9}$ Arquivo Nacional Torre do Tombo. Manuscritos do Brasil. Livro 43. No website Digitarq, o Livro é descrito como "Descrição de Pernambuco", cf. http://digitarq.arquivos.pt/details?id=4493996 e é onde contém a informação do Ex-libris (que passou despercebida por mim).
} 
problemática de que, tendo a última data como Dezembro de I748, não se comprova que ele foi criado em I749, por ordem do Governador da Capitania (como os próximos documentos que irei demonstrar). Entretanto, mesmo sem saber de detalhes de sua História, sua letra, tipo de papel, encadernação e antiguidade, pode remeter ao século XVIII e não para o século XIX, como se o Livro 43 tivesse sido escrito para ser utilizado por futuros administradores da Capitania que necessitassem de documentos de sua História, para traçar planos de governo; e não, portanto, uma cópia aleatória de algum colecionador (ou antiquário) do século XIX, interessado em antiguidades, para compor uma História da Capitania de Pernambuco. Por sinal, Luiz Sávio de Almeida, que usufruiu do Códice transcrito pela Biblioteca Nacional do Rio de Janeiro, faz ressalvas - utilizando de leituras de Vera Lúcia Costa Acioli - sobre possíveis erros e discrepâncias acerca da transcrição do original da Torre do Tombo, para a cópia pertencente à Biblioteca Nacional (ALMEIDA, 2005, p. 338, nota 74$)^{\mathrm{IO}}$. Como a versão que está agora transcrita nesse artigo é a da Biblioteca, interessa chamar a atenção do leitor para esse aviso.

O Documento 02 e Documento 03 podem ser considerados inéditos para a pesquisa sobre a História de Alagoas. Como não se fez pesquisa em Arquivos Pernambucanos como o Arquivo Público, o do Instituto Histórico e em suas revistas, não se pode dizer que suas existências são inéditas em todos os sentidos (pois os pernambucanos, como José Antonio Gonsalves de Mello, são famosos por publicarem fontes diversas da História de Pernambuco encontrados em vários arquivos) (RODRIGUES, I96I). Mas, mesmo assim, por não ter sido citado em trabalhos "alagoanos" e nem transcrito em alguma revista do IHGAL (como foram algumas informações da Informação Geral da Capitania de Pernambuco e da Ideia da População da Capitania de Pernambuco), suas transcrições nesse momento são de imensa valia.

Mais uma vez, a História do Documento 02 é difícil de apanhar. Sabe-se que ele foi escrito entre 1762 e I763, provavelmente por ordem do Governador e Capitão General Luiz Diogo Lobo da Silva em seu último ano de Governo (I756-I763), antes de partir para o Governo da Capitania de Minas Gerais. É um Mapa Estatístico sobre a Capitania de Pernambuco e suas anexas, com informações de população, número de Engenhos, dinheiro de Provedoria, apetrechos de guerra, distribuição de Aldeias de Ameríndios, rapazes aprendendo ofícios, "raparigas" aprendendo a fiar e cozer, número de praças, almas, e até mesmo cabeça de gados e ovelhas. A criação do Documento serve no âmbito da fiscalidade e do governo. O primeiro é no sentido de que, Luiz Lobo da Silva, deveria

\footnotetext{
${ }^{\text {Io }}$ A leitura utilizada por Sávio de Almeida foi de ACIOLI, et al (Orgs.), 1985.
} 
prestar contas sobre como recebeu a Capitania e o que estava deixando antes de partir para a próxima empreitada. Da mesma feita, o segundo âmbito é de deixar para posteriori informações que deveriam ser usadas por futuros Governadores e outros agentes administrativos, que desejassem programar seus planos de Governo e precisavam trabalhar em cima de dados empíricos, para melhor traçarem suas estratégias e ações diretas.

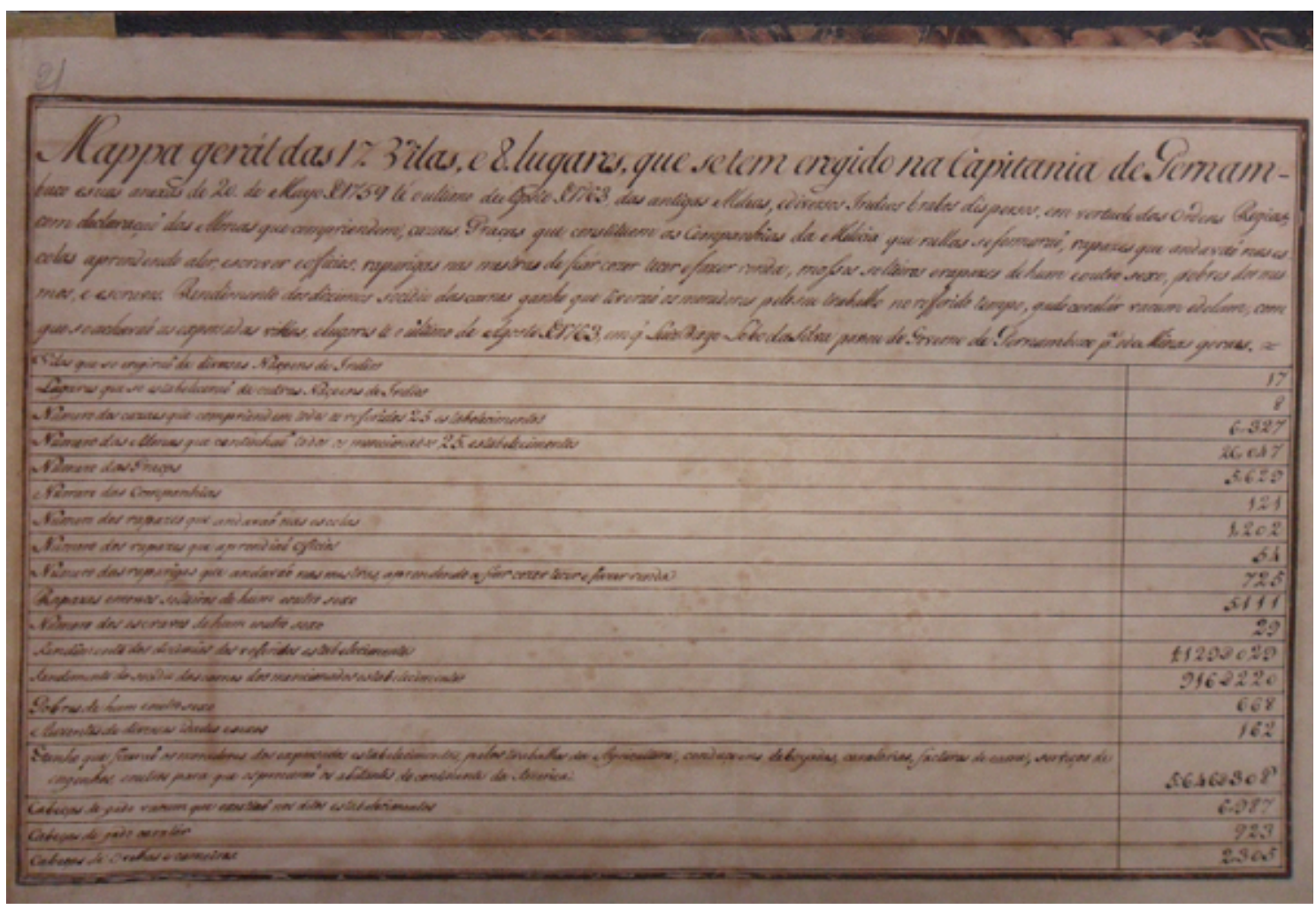

Fólio 3, "Mapa Geral das I7 vilas, e 8 lugares, que se tem erigido na Capitania de Pernambuco e suas anexas de 20 de Maio de $\mathbf{I} 759$ até o último de Agosto de 1763 (...)".

Acervo da Biblioteca Nacional - Rio de Janeiro

O Documento original pode ser encontrado na Biblioteca Nacional do Rio de Janeiro, sob o códice 03, oI, 038 - Mapas estatísticos da Capitania de Pernambuco, I763 (para se pesquisar, é necessário ter o número do Códice e parte de seu título). É composto por um caderno, com capa dura posterior à data em que foi criado (provavelmente feito pela Biblioteca Nacional para melhor conservá-lo. Todavia, peço perdão ao leitor, pois não foi tirada foto ou nota sobre o ex-libris), manuscrito e de 9 fólios. Crê-se que é Original. 


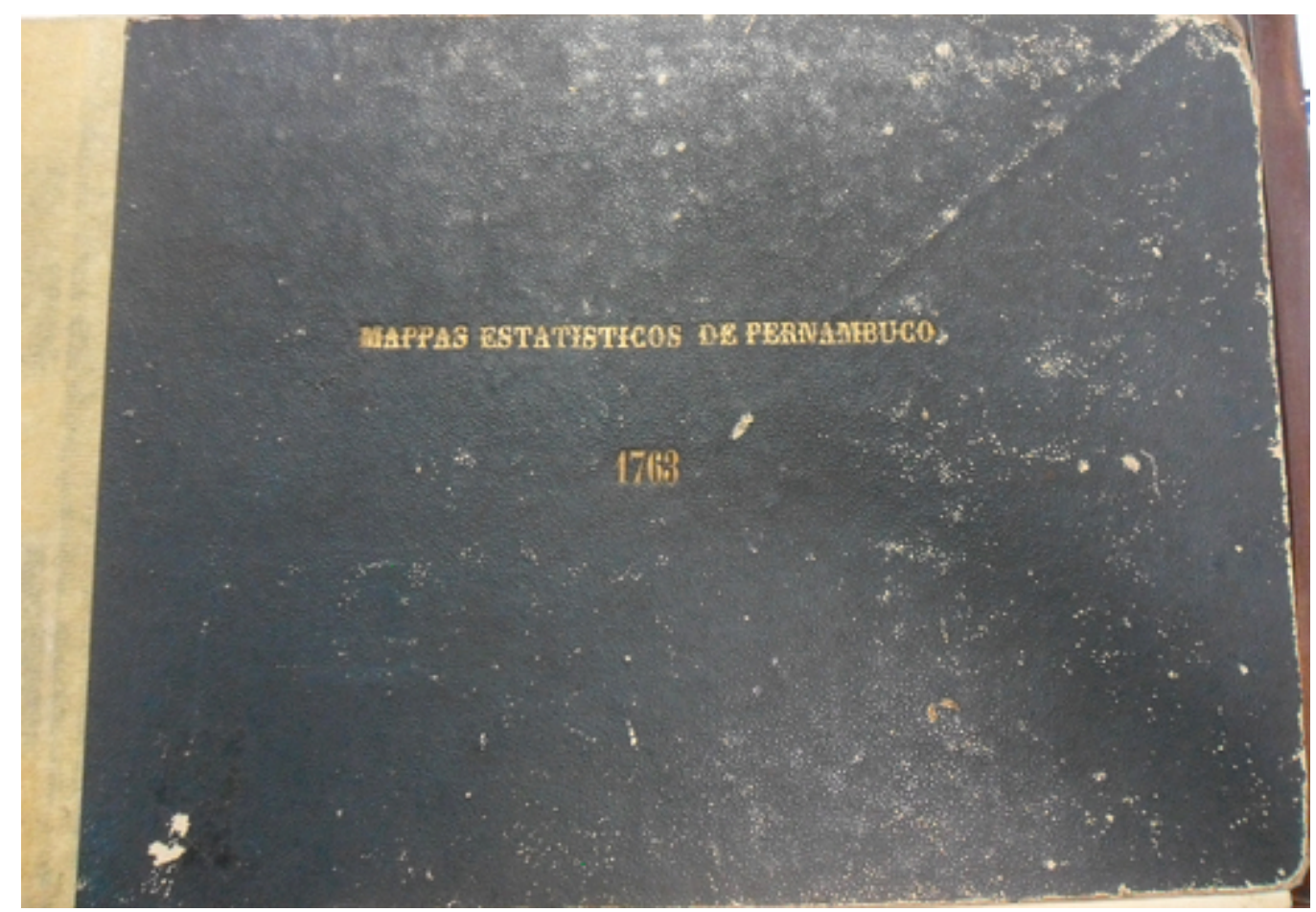

Capa do Códice "Mappas Estatisticos de Pernambuco 1763".

Acervo da Biblioteca Nacional - Rio de Janeiro

O Documento o3 é de delimitação mais confusa. De maneira sintética, é uma relação de todos os Ofícios de Justiça e Fazenda de várias Capitanias, Comarcas e Vilas do Brasil Colonial, feito em $\mathbf{1 7 6 7}$, a pedido do Marquês de Lavradio, na Bahia. Os responsáveis pelo Documento foram os "Conselheiros, Ministros [e] Deputados da Junta da Fazenda, e Fisco Real”. O responsável por registrar nos Livros daquela Provedoria da Fazenda foi o "Desembargador [e] Provedor Mor da Fazenda Real". Ao ser entregue ao Escrivão do Tesouro, a motivação da criação do "caderno" foi de que "por elas regulará a cobrança das Meias Anatas, que pagarem os Providos Serventuários dos ditos Ofícios, e que só aqueles, que não estejam novamente avaliados, cobrará a Meia Anata pelas antigas avaliações que tiverem". Apesar de o fim para o qual o documento foi escrito diga uma ação, a relação dos ofícios listados das vilas de Alagoas, Porto Calvo e Penedo ajudam o pesquisador a traçar o perfil administrativo das localidades naquele ano, ajudando a fazer comparações, especialmente com a relação de ofícios escrita em I749 na Informação Geral da Capitania de Pernambuco. 


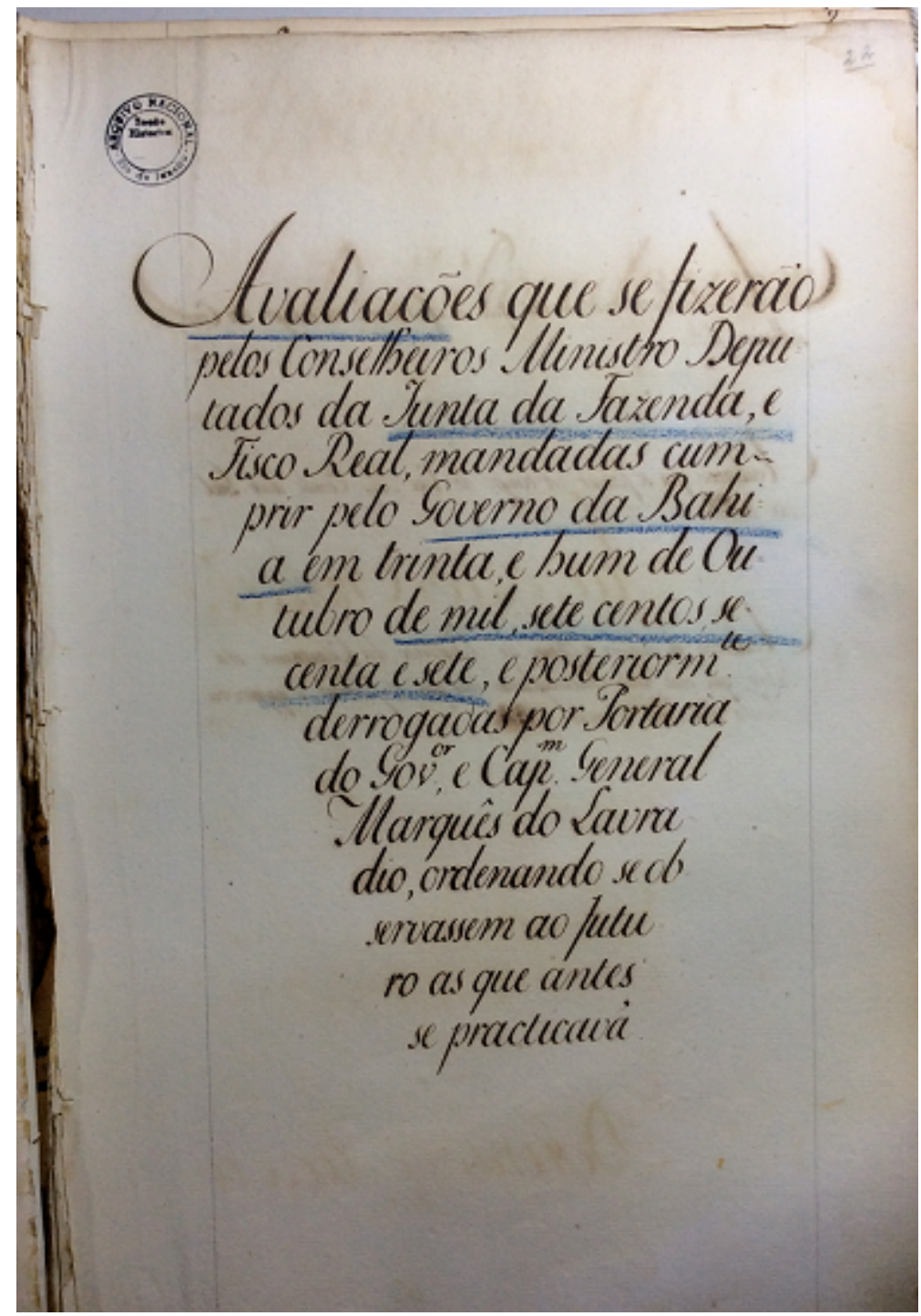

Fólio inicial do documento (referência abaixo).

Acervo do Arquivo Nacional - Rio de Janeiro.

O local onde ele se encontra pode ser qualquer um: Bahia, Pernambuco, Rio de Janeiro, Lisboa ou Coimbra. Mas a impressão que fica é e de que o Fundo/Seção/Caixa/Gaveta é óbvio: Provedoria da Fazenda Real do Estado do Brasil. Nada mais enganoso. Caio Prado Júnior há muito tempo disse que o pesquisador da História do Brasil Colonial deveria estar sempre preparado “(...) para toda sorte de incongruências" (PRADO Jr., 2008, p. 299). O mesmo raciocínio (ou empolgação) deve ser aplicado à pesquisa de "Alagoas Colonial" nos arquivos do Brasil e no exterior. Existente no Arquivo Nacional do Rio de Janeiro, tal Documento faz parte do Fundo do Tribunal da Relação da Bahia - Códice 539, vol. 3, fls. 22 e seguintes. Isso, por exemplo, pode ajudar a explicar o relativo ineditismo dele até os dias atuais. O pesquisador que for para o Arquivo Nacional do Rio de Janeiro, primeiramente, não irá encontrar um espaço em separado chamado 
"Alagoas"; segundamente, mesmo que ele tenha a experiência de que o Arquivo é catalogado por assunto, não existem livros em especiais para Alagoas, às vezes nem mesmo para Pernambuco. Tendo o pesquisador que ir para livros mais ou menos "aleatórios" e procurar ali por documentação diversa.

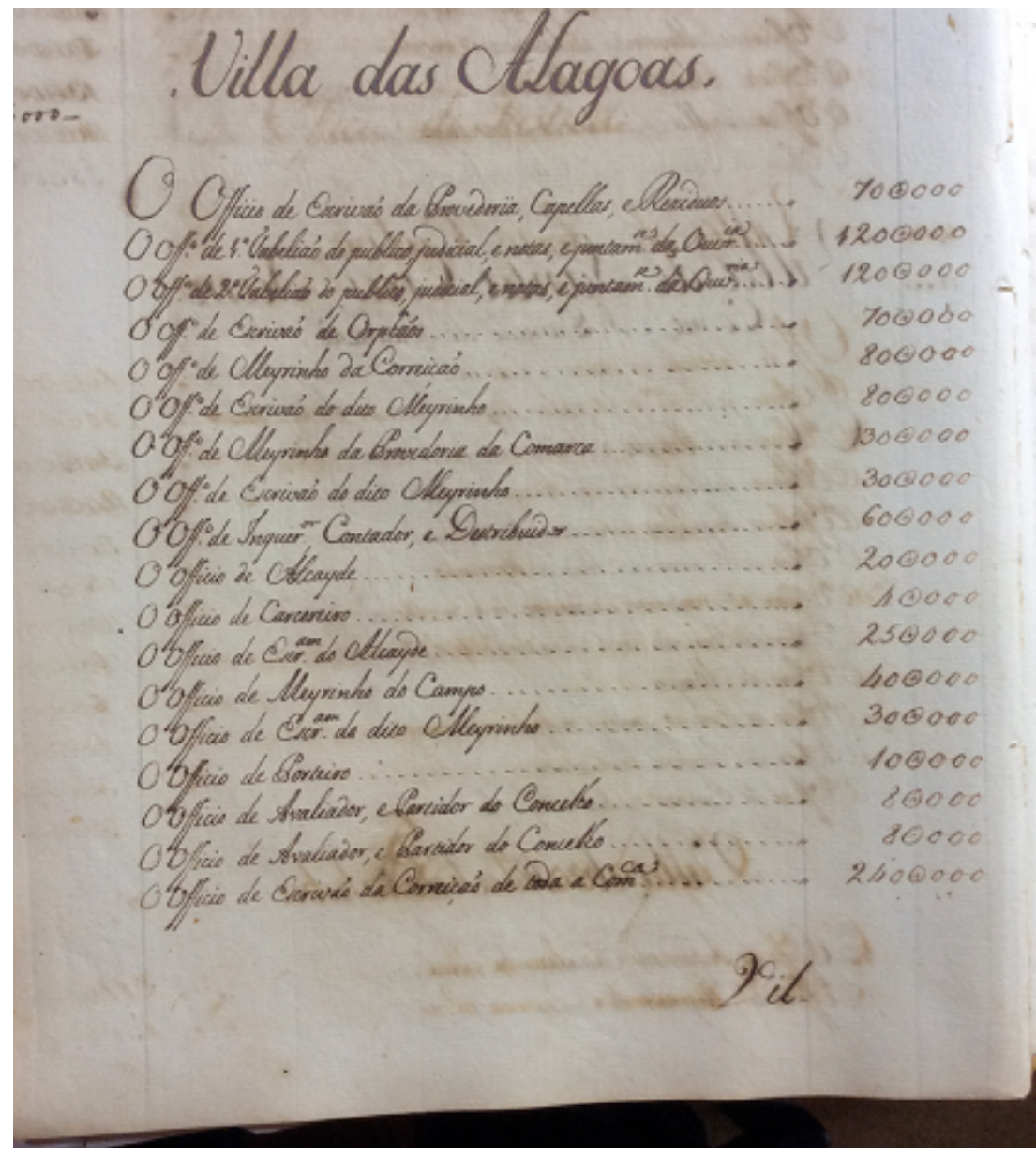

Fólio 5v, [Relação de Ofícios na Villa das Alagoas, i767].

Acervo do Arquivo Nacional - Rio de Janeiro

Momento Confissão de Historiador: esse último documento foi encontrado ao acaso. $\mathrm{O}$ Códice 539, vol. 3 do Tribunal da Relação da Bahia, no Arquivo Nacional, foi pedido por mim para ser analisado um documento sobre relação de Oficiais da Igreja, militares e outros do ano de I626. No Instrumento de Pesquisa do Arquivo Nacional, com resumo de documentação dos códices, nada sobre uma relação de Oficiais de Justiça da Capitania de Pernambuco, Comarca das Alagoas e outras tantas estava exemplificado. Por sorte, me deparei com o documento no início do Códice e pude fotografar para transcrever e agora disponibilizar. Inclusive, a "relação de oficiais da igreja e outros" não tinha data, podendo ser em qualquer ano dos XVII e XVIII. Somente com a pesquisa e a abertura do Códice é que se tomou conhecimento da data ser I626. Ou seja, nem toda pesquisa tem que ser 
sempre certeira, com documentos fixos e de assimilação latente; o pesquisador tem que se acostumar, às vezes, a entrar em territórios pouco ou nada explorados, sem informações, como uma floresta sem placas, caminhos e equipamentos, numa noite nublada sem poder se guiar por pontos cardeais. Essa situação também ajuda a ilustrar de maneira cômica aquele velho ditado: você só acha aquilo que procura quando não o está procurando; ou, em outra versão: para achar algo perdido, procure por outra coisa.

O Documento o4 é um velho conhecido da historiografia alagoana. Junto com a Informação Geral da Capitania de Pernambuco, foi transcrito nos Anais da Biblioteca Nacional e copiado também na Revista do IHGAL. A Ideia da População da Capitania de Pernambuco é recheada de mistérios e problemas. O primeiro ponto é que nada sobre sua História é dito. Nos Anais da Biblioteca Nacional o documento é transcrito logo na primeira página, e no relatório final; nada é falado sobre ele. O que se tem de informação é o título principal da obra:

Ideia da população da Capitania de Pernambuco, e das suas anexas, extensão de suas costas, rios, e povoações notáveis, agricultura, número dos engenhos, contratos, e rendimentos reais, aumento que estes tem tudo etc. etc. desde o ano de 1774 em que tomou posse do Governo das mesmas Capitanias o Governador e Capitão General José César de Menezes (Anais da Biblioteca Nacional do Rio de Janeiro, I923, pp. I-II2).

O título engana. Uma leitura desatenta pode achar que as informações ali contidas, devem ser exclusivamente de i774. Só que aquele ano foi o início do Governo de José César de Menezes, que acabou em 1787. Algumas relações no documento são de I774, outras de I782, e algumas referências (como contratos) extrapolando até I789. O documento contém mapas populacionais, descrições extensas das vilas e freguesias da Comarca das Alagoas, relações de rios, Igrejas, Conventos, Fazendas, fogos, nascimentos, óbitos, engenhos, etc. Nesse ponto, o ideal é deixar por conta das indagações de futuros pesquisadores (mais afinados com os temas de pesquisas) o melhor estabelecimento das datas das informações contidas na Ideia da População da Capitania de Pernambuco. Por hora, mantem-se o recorte da documentação como I774-I787, mas sempre deixando em alerta que no interior do Códice algumas datas estão bem delimitadas e até mesmo erradas.

Outro problema para traçar a História do Documento foi o fato de, por estar publicado nos Anais da Biblioteca Nacional. A possibilidade de consulta ao Original é quase nula, 
devendo o requerente escrever ofício para ser avaliado pelo(a) responsável dos Manuscritos da Biblioteca Nacional. Tendo o "original” em mãos, seria possível saber se é um Códice, ou se são folhas soltas (o que é difícil), se têm páginas rasgadas ou faltando (apesar da credibilidade que se tem nos responsáveis pela transcrição para os Anais da Biblioteca - que alertam quando há faltas -, certa desconfiança sempre existe) ou se tem exlibris caso seja encadernado de época.

De acordo com José Honório Rodrigues: "O original manuscrito encontra-se na Biblioteca da Ajuda [Lisboa]; vide Carlos Alberto Ferreira, Inventários dos Manuscritos da Biblioteca da Ajuda Referentes à América do Sul. A cópia que serviu à edição dos Anais encontra-se registrada no Catálogo de Manuscritos sobre Pernambuco, ABN, 195I, vol. 7I, nº 269, p. 22I" (RODRIGUES, I979, p. 23I, nota 4). Essa informação serve para problematizar que o "Original" da Biblioteca Nacional do Rio de Janeiro já seria a cópia de um possível original. Resta saber - a partir de pesquisas in loco - as características do que seria o “original manuscrito" que está na Ajuda, bem como analisar - como fez Vera Lúcia Costa Acioli para a Informação Geral da Capitania de Pernambuco - possíveis discrepâncias na leitura paleográfica.

O Documento 05 são as Notas Corográficas sobre a Comarca das Alagoas em I8I4 (infelizmente sem foto, pois era proibida sua reprodução). Disponível no Instituto Histórico e Geográfico Brasileiro II. Como o próprio nome diz, são Notas, esparsas e sem ordem fixa. Todavia, tem informações gerais das seis principais Vilas da Comarca das Alagoas (Alagoas, Porto Calvo, Penedo, Poxim, Anadia e Atalaia), com número de habitantes, fogos, negros, pardos e índios. Em seguida é dada uma relação de rios, tipo de economia e terreno que cobre a Comarca. Uma tabela sobre a população detalhada da Freguesia da Vila das Alagoas aparece de autoria do Vigário Antonio Gomes Coelho. Seu relato, escrito atrás da tabela, é de riqueza ímpar, sobre a vida dos habitantes, o tipo de casa, famílias, engenhos de açúcar, fazendas diversas, nível de riqueza, relação com as lagoas, ilhas e enchentes, etc. Ao final do documento, o Ouvidor das Alagoas, Antonio Batalha, escreve suas notas, bem simples, como se tivesse o intuito de delimitar qual das vilas merecia um melhor ordenamento administrativo.

Todavia, é impossível saber a origem das Notas Corográficas, pois esse não é o "nome" do documento e não está escrito em nenhum local. Supõe-se que é uma caracterização artificial, criado pelo responsável da catalogação do documento nas fichas do Instituto Histórico e Geográfico Brasileiro. O Documento, em si, não tem abertura. Esse

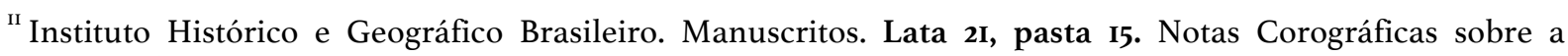
Comarca das Alagoas em I8I4.
} 
tipo de fonte, quando é escrito, recebe títulos, normalmente acompanham as palavras "Relação", "Descrição", "Mapa”, etc. A palavra Corografia não é comum (apesar de existir no século XVIII, pois D. Bluteau a relaciona em seu dicionário). Dizer que o Título está errado também é arriscado e pode representar uma afronta, pois se estaria diminuindo a disciplina da Geografia como responsável apenas pelo estudo da terra (o clima para climatologia, os oceanos e mares para topografia, e assim por diante), ignorando a Geografia Humana, Demografia como ramificação da Geografia (não apenas da História e da Economia, por exemplo). Por ser um Instituto Histórico e Geográfico, fundado no século XIX, por D. Pedro II, não é de se espantar que esse Documento tenha recebido essa nomenclatura.

Inclusive, até as folhas são diferentes; assim como as letras, o que pode demonstrar que o responsável pela catalogação ou o doador juntou 3 documentos diferentes (que contabilizam 4 fólios) e o transformou em um Documento por conta das informações nele contidas. Eles foram despedaçados de outros relatórios? Existiram outros escritos como o do Vigário Antonio Gomes Coelho? Impossível saber, por enquanto...

Esses são os Cinco Documentos para a História de Alagoas. Tentou-se fazer uma pequena introdução sobre a História de cada um, mas sem ficar enumerando, de maneira mais ou menos incisiva, as possibilidades de pesquisa a partir deles (o que poderia induzir e viciar análises). Devem caber ao pesquisador as problematizações.

\section{A Original Função dos Documentos}

Após passar por essas linhas, não é nenhum crime estabelecer, a partir de sua História, a função do Documento para aquela época. Ressalta-se novamente que, a partir da ótica e das problemáticas do Historiador, o Documento é extrapolado para o uso diverso no trabalho do fazer-se da História (e, nisso, a epígrafe de Edward Thompson é inspiradora).

Para juntar as peças do quebra-cabeça com mais cuidado, insere-se essas fontes em sua época em que foram produzidos: uma Monarquia Corporativa (até meados de I700) e Policial (após ascensão de Pombal do poder), detentora de um Império que se espalhava pelos quatro cantos do globo. Por conta da divisão de atribuição do Rei a seus oficiais e instituições, a Administração era fragmentada e a troca de informações e planos de conquista e governo era dada especialmente via Documentos escritos, como cartas, alvarás, petições, requerimentos, etc. (HESPANHA \& SUBTIL, 20I4). Esse tipo de literatura não era exclusivo dos altos cargos em relação a um Centro (SUBTIL, I992); mas perpassava entre os próprios administradores, como trocas de informações e conhecimentos para estabelecer 
melhor os métodos e táticas de controle e conquista a partir de Redes Governativas (GOUVÊA, 20IO, 20I0).

As Relações, Mapas Estatísticos, "Corografias", serviam tanto como troca de informações, como para conhecimento histórico de uma localidade que a todo o momento recebia novas pessoas para administrá-la (Capitães, Governadores Gerais, Ouvidores, etc). Se os Oficiais eram proibidos de fincarem raízes e a rotatividade deveria impedir as relações próximas deles com os habitantes locais, os documentos produzidos e deixados nas secretarias de cada Capitania serviam como entrega de dados de que o novo administrador precisaria para traçar seus planos de governo.

Porém, não apenas no sentido político e cultural, como no estatístico e econômico. Se o Estado lusitano é Corporativo e Policial, ao mesmo tempo o é Mercantil Burocrático; ou seja, do mesmo modo em que as conquistas iam se tornando mais sólidas (sem descartar as perdas e derrotas, pois era um Império oscilante), e a Economia ia ganhando seu espaço na construção do Estado, o aparelhamento do Estado lusitano ia se tornando mais "coerente", e as conexões entre a Monarquia e suas Instituições trabalhavam por mais eficácia e comunicação (GODINHO, 1968; GODINHO, 1990, pp. 57-I50). A influência do tipo de administração a partir da Economia Política francesa "colbertiana" no XVII (tendo na figura de Duarte Ribeiro de Macedo seu maior entusiasta e no ministro português D. Luís de Meneses, o $3^{\circ}$ Conde de Ericeira a alcunha histórica de "Colbert português") e inglesa no XVIII (sendo Pombal seu propagandista) pode ter alguma relação na contínua criação de Relações, Mapas Estatísticos, "Corografias" e documentos vários que desnudassem aspectos econômicos e geográficos (HANSON, I986, p. I82 e seguintes; GODINHO, I990, pp. 484 e seguintes).

Todavia, o Império lusitano não se tornou econômico ou mais preocupado com a Economia apenas no XVII e chegando ao seu ápice no XVIII. As próprias motivações de conquista e navegações tinham a riqueza e a exploração de novos mercados em seu núcleo: “(I) o fervor empenhado na cruzada contra os muçulmanos; (2) o desejo de se apoderar do ouro da Guiné; (3) a procura de Preste João; (4) a busca de especiarias orientais" (BOXER, 2002, p. 34). Com o decorrer da expansão, principalmente a americana, a Coroa estabeleceria a economia como ponto fulcral de motivação de conquista, como bem sintetizou Stuart Schwartz:

de certo modo, podemos afirmar que o quanto mais pobre fosse a área colonial e mais baixo o seu nível de riqueza, mais fracas eram as ligações 
com a metrópole, também muito possivelmente mais fraco era o interesse que a metrópole lhe dispensava (SCHWARTZ, 1998, p. 152).

Esses motivos são mais bem apreendidos quando inseridos dentro do método da Economia Política, ciência cara ao século XVIII. Um de seus maiores estudiosos, Karl Marx, o desenvolveu da seguinte forma: "a anatomia da sociedade civil deve ser procurada na economia política" (MARX, 2003, p. 4). Por “anatomia”, pode-se estabelecer:

Quando consideramos um determinado país do ponto de vista da economia política, começamos por estudar a sua população, a divisão desta em classes, a sua repartição pelas cidades, pelo campo e à beira-mar, os diversos ramos da produção, a exportação e a importação, a produção e o consumo anuais, os preços das mercadorias, etc (idem, ibidem).

Não se pretende estabelecer a Economia Política marxista apenas no âmbito da construção do Estado monárquico ${ }^{\mathrm{I2}}$. As posições de um "sentido da colonização" (Caio Prado Júnior), bem como de uma Economia interna (João Fragoso e Manolo Florentino), somando com a utilização dos recursos do Ultramar, não para aparelhar e enriquecer exclusivamente a Monarquia, mas para pagar as rendas das grandes casas portuguesas (Nuno Gonçalo Monteiro) e equilibrar suas balanças no mercado europeu (Noya Pinto; Sandro Sideri), devem ser sempre postas umas contra as outras para dialogar em conjunto, sabendo que uma pode se sobrepor à outra em algumas análises e focos de estudo. O que elas terão em comum é, em boa parte, a Documentação das Relações, os Mapas Estatísticos e os "Corográficos" (PRADO Jr., 2008; FRAGOSO \& FLORENTINO, 200I; MONTEIRO, 20IO; PINTO, I979; SIDERI, I978).

$\mathrm{Na}$ verdade, é bem difícil encarar a real finalidade dos documentos que transcrevemos aqui, e a motivação de ordem cultural e econômica. Primeiro culturalmente, seja qual fosse o estilo de escrita, do documento, e/ou sua finalidade imediata, ele sempre era escrito visando o engrandecimento da Monarquia, seu fim último era o Rei e o Império, logo, o bem comum. Segundo, economicamente, como foi hipotetizado em linhas passadas, a documentação escrita das relações, mapas estatísticos e "corográficos" faziam parte de Secretarias e da administração internas de Capitanias, sendo informações passadas

\footnotetext{
${ }^{12}$ Até porque Marx dá uma aula sobre como seu caminho na Economia Política não se iniciou na "Economia", mas no estudo da Jurisprudência acerca de "roubos de lenha e a divisão da propriedade imobiliária", cf. Idem ibidem, p. 4. Em relação à "anatomia" da Economia Política, seu método utiliza daqueles dados expostos acima em destaque, mas os trabalha em constante dialética, cf. Idem, p. 247-248. O estudo sobre o roubo de linha está atualmente disponibilizado, cf. MARX, 2017.
} 
também oralmente ou por correspondências entre Oficiais que resguardavam a administração e o governo das conquistas. Ou seja, a Economia Política, desenvolvida com contribuições desse tipo de Documento e nas informações nele contidas, não deve ser utilizada apenas para garantir a estruturação exclusiva do Estado (como se estivessem em um governo onde todas as informações deveriam ir para o Centro, para depois serem repartidas às suas partes, de maneira filtrada e racional, impedindo as comunicações horizontais e autônomas). Portanto, real finalidade é completamente diferente de verdadeira finalidade, pois as posições ideológicas e a crítica do estudioso são pontos fulcrais para que o Historiador não seja pego na armadilha de estudar a sociedade (e seus documentos) exclusivamente sob o ponto de vista deles. Marx já escrevia a crítica no século XIX:

O próprio conceito de riqueza nacional se insinua na obra dos economistas do século XVII - a ideia subsiste ainda em parte nos do século XVIII - desta forma: a riqueza é criada unicamente pelo Estado, e o poder deste mede-se por esta riqueza. Esta era a forma ainda inconscientemente hipócrita que anuncia a ideia que faz da própria riqueza e da sua produção o objetivo final dos Estados modernos, considerados assim exclusivamente como meios de produzir a riqueza (MARX, 2003, p. 258).

\section{Notas de edição}

Algumas palavras finais devem ser proferidas. Como os Documentos foram transcritos e copiados, fiz algumas modificações que julguei essenciais. Para evitar poluir os apêndices com notas explicativas em demasia, decidiu-se colocá-las aqui para consulta prévia.

\section{Manipulação dos documentos}

A transcrição foi feita de maneira corrida, sem enumeração das linhas em separado. As informações extras, adições e correções estarão entre colchetes. A adaptação do vocabulário foi feita para os dias atuais, tanto para os manuscritos como para as cópias dos Anais da Biblioteca Nacional. As transcrições do Documento 02 e Documento 05 foram feitas na íntegra. O Documento 03 foi manipulado no sentido de privilegiar somente as Vilas de Alagoas, Porto Calvo e Penedo, deixando de lado outras vilas de Pernambuco e suas 
Capitanias Anexas (mas que foram fotografadas para compor uma transcrição mais "completa" que ficará no acervo do GEAC). O Documento or e Documento o4 foram recortados em exclusivo para "Alagoas" quando receberam transcrição na Revista do IHGAL, e, mesmo assim, outras informações que julguei importantes estiveram descartadas pelo copista. Para esse Apêndice, recopiei as partes relacionadas a Comarca das Alagoas, adicionei informações da Capitania de Pernambuco (seu centro) e, mesmo a contragosto de muitas pessoas, mantive a grafia da maioria dos Rios, corrigindo no geral os nomes das Freguesias e Vilas para um melhor entendimento.

Outra manipulação está relacionada à criação de quadros. A maioria das informações na documentação "original” (seja manuscrita ou nos Anais da Biblioteca Nacional) é por extenso. As que representam relações e números são normalmente separadas por pontos (p. ex. "Vila das Alagoas.............................x.xxx [fogos]"). Decidiu-se, portanto, manipular tais informações criando quadros (o que normalmente já seria feito por pesquisadores mais experientes em alguns trabalhos); em suma, crê-se que ao fazer isso, garantiu-se uma leitura mais rápida dos dados e, inclusive, pode se tornar um modelo para "copiar-e-colar" em outros trabalhos; soma-se que tal manipulação não descartaria a reescrita dos elementos em forma por extensa. De antemão já pode se deixar o aviso de que as tabelas não são imutáveis ou protegidas por algum tipo de copyright tradicional. Futuras manipulações e rearranjos devem ser uma regra, e não uma exceção.

\section{Disponibilidade na Internet}

Para os interessados na documentação "original", ou aqueles que não concordam com manipulações, a existência do Documento or e Documento o4 estão disponíveis online no website da Biblioteca Nacional do Rio de Janeiro (os links serão postos no início de cada apêndice). Ter acesso à matriz é interessante para poder colher outras informações. Na verdade, é até obrigatório que o pesquisador vá para o "original", visto que a Informação Geral da Capitania de Pernambuco é um Códice recheado de documentos de época. O que foi copiado foram as relações mais estatísticas e exatas. Alguém que queira se enveredar na pesquisa da História de Alagoas Colonial é praticamente constrangido a passar os olhos e estudar o Códice por inteiro. Senão, pouco, ou quase nada, vai entender dele.

\section{Disponibilidade no Acervo do GEAC}


Se o Documento or e Documento o4 estão online, o que acontece com o Documento o2, Documento 03 e Documento 05? Ficarão eternamente na Revista Eletrônica e no Hard Drive de quem o transcreveu, disponível apenas aos seus amigos mais próximos ou quem ele decidir ser o escolhido para receber em mãos, mediante um cerimonial pomposo de entrega do que seria um presente valioso? Por enquanto sim, mas que seja por um tempo minúsculo e determinado. Como foi escrito nos primeiros parágrafos desse texto, é projeto do GEAC criar um Banco de Dados, um acervo para deixar disponível a documentação transcrita e recolhida de outros Arquivos, que seja de difícil pesquisa para quem não têm meios e fundos para persegui-los pessoalmente. O projeto no início surtiu efeito, estando no website do GEAC a disponibilidade de boa parte da documentação do Arquivo Histórico Ultramarino - Capitania das Alagoas (doc. I-297, referentes ao período de I680 até I80o); além de outros documentos com as Ordenações Filipinas e links de websites como a Torre do Tombo, Ius Lusitaniae, etc. Infelizmente, por conta do ataque de um Hacker, uma mudança de endereço teve que ser feita e a documentação do AHU transcrita que estava acessível se perdeu. Espera-se que, em breve, o website do GEAC possa voltar à disponibilidade de um público geral.

Contudo, enquanto isso não acontece (pois demanda tempo), uma confiança cega na informática não é bem a melhor alternativa. Já que outros problemas podem acontecer com o tempo (queda de servidor, lentidão, ataque de hacker, perda de dados, destruição de $H D$, formatação de computadores, tomada de consciência das máquinas, escravidão dos humanos e apocalipse digital), o GEAC se encontra no momento em processo de organização de um Acervo Físico de documentação transcrita e publicada por outras iniciativas. O objetivo é que seja aberto a todos os interessados para consulta local e que sirva, pelo menos, para suprir necessidades de pesquisa imediatas (desde que não descartem as idas aos Arquivos quando for possível).

\section{A (in)utilidade desse artigo}

Depois de tantas páginas, a impressão que fica é: esse artigo é inútil. Qual o motivo de gastar essas folhas se a documentação original e suas transcrições estarão Online e disponíveis em formatos físicos em um local de acesso livre? O autor está pensando em angariar algum tipo de benefício?

Essas perguntas são bem previsíveis. Afinal, em um mundo acadêmico recheado de documentos escondidos, informações não-divulgadas e referências documentais incompletas, fica suspeito alguém aparecer com documentos transcritos que deverão ser 
citados em conjunto com o nome de quem transcreveu e o título do presente artigo. Tudo, então, se resume ao Currículo Lattes e a produção acadêmica insana (e às vezes non-sense) no qual estamos inseridos e que é bem difícil escapar? Faço a volta para três pequenos trechos desse artigo.

I) Defender a pesquisa e problematização dinâmica de Documentos.

2) Alargar a pesquisa e a leitura de outras evidências para além das Informação da Capitania de Pernambuco e Ideia da População de Pernambuco.

3) Disseminar a proposta de construção de um Acervo de Documentos do GEAC e sua disponibilização e socialização em formato físico e digital, por meio de website.

Com todo o respeito aos usuários das mídias sociais, a melhor maneira de expor esses argumentos e trabalhos em andamento é a partir de um estudo, cientificamente conduzido e apropriadamente divulgado ${ }^{13}$. Divulgar em um post em alguma rede social que "tem documento novo na praça”, apesar de ser uma atitude, à primeira vista, altruísta, é um chamado para consequências posteriores.

Poderá acontecer que esse artigo seja único, que não mais apareça em futuras revistas ou livros do GEAC algo parecido, com transcrições e etc., estando os documentos e guias de pesquisa disponibilizados no website e em formato físico no Acervo (com suas devidas introduções explicativas, é óbvio). Mas, como uma espécie de introdução a esse retorno ao Projeto do Banco de Dados, é-se necessário escrever esse tipo de texto.

\section{Referências Bibliográficas}

ALMEIDA, Luiz Sávio de. Memorial biográfico de Vicente de Paula, capitão de todas as matas: guerrilha e sociedade alternativa na mata alagoana. - Maceió: EDUFAL, 2008.

ALMEIDA, Luiz Sávio de. "Escravidão e Maceió: distribuição espacial e renda em I856". In: MACIEL, Osvaldo. (org.). Pesquisando (n)a província: economia, trabalho e cultura numa sociedade escravista (Alagoas, século XIX). - Maceió: Q Gráfica, $20 I I$.

Anais da Biblioteca Nacional do Rio de Janeiro. Volume XXVIII, 1906. - Rio de Janeiro: Officinas de Artes Graphicas da Bibliotheca Nacional, 1908.

\footnotetext{
${ }^{13}$ Tomo a expressão de Lucien Febvre: "A história que é toda ela social, por definição. A história que considero o estudo, cientificamente conduzido (...)" (FEBVRE, I983, p. 30). Sobre a ideia de "apropriadamente divulgado", importante a leitura de TAVARES, 2012.
} 
Anais da Biblioteca Nacional do Rio de Janeiro. Volume XL, I9I8. - Rio de Janeiro: Officinas Gráphicas da Biblioteca Nacional, 1923.

BARROS, José D’Assunção. Teoria da História. 5 volumes. - Petrópolis, RJ: Vozes, 2014. BLOCH, Marc. Apologia da história, ou, O ofício de historiador. - Rio de Janeiro: Jorge Zahar Ed., 200I.

BLUTEAU, Raphael. Vocabulario portuguez \& Latino: áulico, anatomico, architectonico... Coimbra: Collegio das Artes da Companhia de Jesus, I7I2-I728 (8v.).

BOXER, Charles. O império marítimo Português. I415-I825. - São Paulo: Companhia das Letras, 2002.

BRAUDEL, Fernand. História e Ciências Sociais. Lisboa: Editorial Presença, 1972.

BURKE, Peter. História e teoria social. - 2 ed. ampl. - São Paulo: Editora Unesp, 2012.

CAETANO, Antonio Filipe Pereira (org.). Alagoas e o império colonial português: ensaios sobre poder e administração (séculos XVII - XVIII). Maceió: Cepal, 20 oı.

CAETANO, Antonio Filipe Pereira (org.). Alagoas Colonial: Construindo Economias, Tecendo Redes de Poder e Fundando Administrações (Séculos XVII-XVIII). Recife: Editora Universitária UFPE, 2012.

CAETANO, Antonio Filipe Pereira (org.). Das partes sul à Comarca das Alagoas, capitania de Pernambuco: ensaios sobre justiça, economia, poder e defesa (século XVIIXVIII). - Maceió: Viva Editora, 2015.

CAETANO, Antonio Filipe Pereira (org.). De Comarca à Província das Alagoas: Poder, Administração e Escravidão (Século XVII-XIX). 2017.

CARDOSO, Ciro Flamarion. BRIGNOLI, Héctor Pérez. Os métodos da história. - Rio de janeiro: Edições Graal, 6ª ed. 2002.

CARDOSO, Ciro Flamarion. VAINFAS, Ronaldo. Domínios da História. $-2^{\mathrm{a}}$ ed. - Rio de Janeiro: Elsevier, 20II.

CARDOSO, Ciro Flamarion \& VAINFAS, Ronaldo. (orgs.) Novos domínios da história. Rio de Janeiro: Elsevier, 2012.

CARVALHO, Flávia Maria de. SILVA, Gian Carlo de Melo (orgs.). África e Brasil: histórias que cruzam o atlântico. - Maceió: EDUFAL, 2017.

CERTEAU, Michel de. “A operação historiográfica”. In: CERTEAU, Michel de. A escrita da história. - Rio de Janeiro: Forense Universitária, 2010.

CIPOLLA, Carlo M. Introdução ao estudo da história económica. - Lisboa: Edições 70, 1993.

COSTA, F. A. Pereira da. Anais pernambucanos I740-I794. - Recife: Fundarpe. Diretoria de Assuntos Culturais, 1984 
DIÉGUES Jr. Manuel. O banguê nas alagoas: traços da influência do sistema econômico do engenho de açúcar na vida e na cultura regional. - Maceió, EDUFAL, 2006.

DOSSE, François. A história em migalhas: dos “Annales" à "Nova História”. - São Paulo: Ensaio; Campinas, SP: Editora da Universidade Estadual de Campinas, 1992.

FEBVRE, Lucien. "De I892 a I933. Exame de consciência de uma história e de um historiador". In: FEBVRE, Lucien. Combates pela história. - Lisboa: Editorial Presença, 1989.

FEBVRE, Lucien. "Viver a história: palavras de iniciação". In: FEBVRE, Lucien. Combates pela história. - Lisboa: Editorial Presença, 1989.

FERREIRA, Aurélio Buarque de Holanda. Dicionário Aurélio da Língua Portuguesa: básico. Editora Nova Fronteira, 1988

FRAGOSO, João. FLORENTINO, Manolo. O arcaísmo como projeto: mercado atlântico, sociedade agrária e elite mercantil em uma economia colonial tardia: Rio de Janeiro, c. I790 - c.I840. - Rio de Janeiro: Civilização Brasileira, 200 I.

FRAGOSO, João. GUEDES, José Roberto. SAMPAIO, Antonio Carlos Jucá. (org.). Arquivos paroquiais e história social na América lusa, séculos XVII e XVIII: métodos e técnicas de pesquisa na reinvenção de um corpus documental. - Rio de Janeiro: Mauad X, 2014.

FOUCAULT, Michel. A Arqueologia do saber. - Rio de Janeiro: Forense Universitária, 2012.

GODINHO, Vitorino Magalhães. "Finanças públicas e estrutura do Estado". In: GODINHO, Vitorino Magalhães. Ensaios II, sobre a história de Portugal. Lisboa: livraria Sá da Costa Editora, 1968.

GODINHO, Vitorino Magalhães (org.). A história social: problemas, fontes e métodos. Colóquio da Escola Normal Superior de Saint-Cloud (I5-I6 de Maio de 1965). Lisboa: Edições Cosmos, 1973.

GODINHO, Vitorino Magalhães. "As frotas do açúcar e as frotas do ouro, I670-I770”. In: GODINHO, Vitorino Magalhães. Mito e mercadoria, utopia e prática de navegar. Séculos XIII-XVIII. Lisboa: Difel: 1990

GOUBERT, Pierre. “As fontes modernas: os séculos XVII e XVIII”. In: GODINHO, Vitorino Magalhães (org.). A história social: problemas, fontes e métodos. Colóquio da Escola Normal Superior de Saint-Cloud (I5-I6 de Maio de 1965). Lisboa: Edições Cosmos, 1973.

GOUVÊA, Maria de Fátima. "Poder político e administração na formação do complexo atlântico português. (I645-I808)”. In: FRAGOSO, João. BICALHO, Maria Fernanda Baptista. GOUVÊA, Maria de Fátima Silva (orgs.). O Antigo Regime nos trópicos: a dinâmica 
imperial portuguesa (séculos XVI - XVIII). - $2^{\mathrm{a}}$ ed. Rio de Janeiro: Civilização Brasileira, 2010.

GOUVÊA, Maria de Fátima. "Redes governativas portuguesas e centralidades régias no mundo português, c. I689-I730”. In. FRAGOSO, João. Gouvêa, Maria de Fátima (orgs.). Na trama das redes: política e negócios no império português, séculos XVI - XVIII. - Rio de Janeiro: Civilização Brasileira, 20 Io.

HANSON, Carl A. Economia e sociedade no Portugal barroco. - Lisboa: Publicações Dom Quixote, 1986.

HESPANHA, António Manuel \& SUBTIL, José Manuel. "Corporativismo e Estado de polícia como modelos de governo das sociedades euro-americanas do Antigo Regime”. In: FRAGOSO, João. GOUVÊA, Maria de Fátima. O Brasil Colonial: volume I (ca. I443ca.I580). - Rio de Janeiro: Civilização Brasileira, 2014.

HOBSBAWM, Eric. Sobre História. - São Paulo: Companhia das Letras, 1998.

LE GOFF, Jacques. CHARTIER, Roger. REVEL, Jacques. (dir.) A Nova História. Coimbra: Almedina, I990.

LE GOFF, Jacques. “Documento/Monumento”. In: LE GOFF, Jacques. História e Memória. - Campinas, SP: Editora da UNICAMP, 2003.

LINDOSO, Dirceu. A utopia armada: Rebeliões de pobres nas matas do Tombo Real. - 2. ed. rev. - Maceió: EDUFAL, 2005.

LINDOSO. Dirceu. Interpretação da província: estudo da cultura alagoana. - 3. ed. rev. amp. - Maceió: EDUFAL, 2015.

MACIEL, Osvaldo. (org.). Pesquisando (n)a província: economia, trabalho e cultura numa sociedade escravista (Alagoas, século XIX). - Maceió: Q Gráfica, $201 I$.

MARX, Karl. Contribuição à crítica da economia política. - São Paulo: Martins Fontes, 2003.

MARX, Karl. Os despossuídos: debates sobre a lei referente ao furto de madeira. - São Paulo: Boitempo, 2017.

MAURO, Frédéric. Nova história e novo mundo. São Paulo: Editora Perspectiva, 1969.

MELLO, José Antonio Gonsalves de. "Pereira da Costa e suas fontes históricas: Acervos de documentação utilizados nos Anais Pernambucanos”. In: COSTA, A. F. Pereira da. Anais Pernambucanos I493-I590. - Recife: Fundarpe. Diretoria de assuntos culturais, 1983

MENESES, Ulpiano T. Bezerra. "História e imagem: iconografia/iconologia e além". In: CARDOSO, Ciro Flamarion \& VAINFAS, Ronaldo. (orgs.) Novos domínios da história. Rio de Janeiro: Elsevier, 2012. 
MONTEIRO, Nuno Gonçalo. “Trajetórias sociais e governo das conquistas: Notas preliminares sobre os vice-reis e governadores-gerais do Brasil e da Índia nos séculos XVIIXVIII". In: FRAGOSO, João. BICALHO, Maria Fernanda Baptista. GOUVÊA, Maria de Fátima Silva (orgs.). O Antigo Regime nos trópicos: a dinâmica imperial portuguesa (séculos XVI - XVIII). - 2a ed. Rio de Janeiro: Civilização Brasileira, 20 o.o.

PINTO, Luiz Maria da Silva. Diccionario da Lingua Brasileira por Luiz Maria da Silva Pinto, natural da Provincia de Goyaz. Na Typographia de Silva, I832.

PINTO, Virgílio Noya. O ouro brasileiro e o comércio anglo-português: uma contribuição aos estudos da economia atlântica no século XVIII. - 2. ed. - São Paulo: Editora Nacional, I979.

PRADO JÚNIOR, Caio. Formação do Brasil contemporâneo: colônia. - São Paulo: Brasiliense, 2008

Revista do Instituto Arqueológico e Geográfico Alagoano, Volume XII. 1927

RODRIGUES, José Honório. "Índice anotado da Revista do Instituto Arqueológico e Geográfico Pernambucano”. Revista do Instituto Arqueológico Histórico e Geográfico Pernambuco. Vol. XLIV, I954-I959. Pernambuco, I96I

RODRIGUES, José Honório. História da história do Brasil: $\mathrm{I}^{\mathrm{a}}$ parte Historiografia colonial. - São Paulo: Ed. Nacional, 1979

SANT'ANA, Moacir Medeiros de. Contribuição à história do açúcar em Alagoas. Recife: Instituto do Açúcar e do Alcool. Museu do Açúcar, I970.

SCHWARTZ, Stuart. "O Brasil no Sistema Colonial”. In. BETHENCOURT, Francisco. CHAUDHURI, Kirti. (dir.) História da Expansão Portuguesa vol. III: O Brasil na Balança do Império (I697-I808). Lisboa: Temas e debates, 1998.

SIDERI, Sandro. Comércio e poder. Colonialismo informal nas relações angloportuguesas. - Lisboa: Editora Cosmos, 1978.

SILVA, Antonio Moraes. Diccionario da língua portuguesa - recompilado dos vocabulários impressos até agora, e nesta segunda edição novamente emendado e muito acrescentado. Vol. 2 - I789. Lisboa: Typhografia Lacerdina, I8I3

SUBTIL, José. “Os poderes do centro”. In: HESPANHA, António Manuel. (coord.). História de Portugal, o antigo regime (vol. IV). Dir. José Mattoso. Lisboa: editorial estampa, 1992.

TAVARES, Célia Cristina da Silva. "História e Informática". In: CARDOSO, Ciro Flamarion. VAINFAS, Ronaldo (orgs.). Novos Domínios da História. - Rio de Janeiro: Elsevier, 2012.

THOMPSON, Edward Palmer. A formação da classe operária inglesa: a força dos trabalhadores, vol. III. - Rio de Janeiro: Paz e Terra, I98I. 
VARNHAGEN, Francisco Adolfo de. História Geral do Brasil: antes da sua separação e independência de Portugal. $5^{\mathrm{a}}$ edição integral. - São Paulo: Edições Melhoramentos, 1956. VIEIRA, Daniel de Souza Leão. "Frans Post e o carro de bois: o imaginário da paisagem do Brasil holandês". Revista do Instituto Arqueológico, Histórico e Geográfico Pernambucano. n. 67. - Recife, 2014.

VILAR, Pierre. Desenvolvimento económico e análise histórica. - Lisboa: Editorial Presença, 1982.

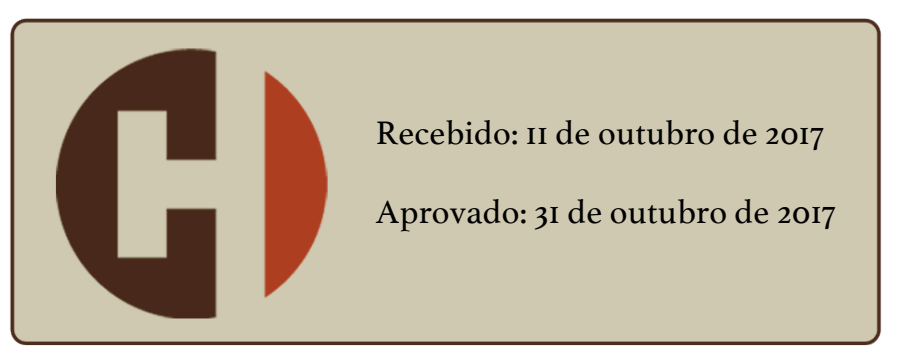

